\title{
Analysis of Civic Skill in the Student Exchange Program Merdeka Belajar - Kampus Merdeka Policy
}

\author{
Susan Fitriasari ${ }^{1,}$, Nisrina Nurul Insani ${ }^{2,{ }^{*}}$ Dede Iswandi ${ }^{3}$, Sarah Raudlatul Aulia ${ }^{4}$
}

\author{
1,2,3,4 Universitas Pendidikan Indonesia, Bandung, Indonesia \\ ${ }^{*}$ Corresponding author. mail: nisrina.n.i@upi.edu
}

\begin{abstract}
Civic skills need to be possessed by students to improve their quality in facing the challenges of the global world. Today's problems, such as unemployment and poverty, occur due to low student civic skills. Civic skills cannot develop if students are not given the opportunity to develop them. Therefore, the government makes a policy to provide opportunities for students to improve their competence as a whole and are ready to work, namely the Merdeka BelajarKampus Merdeka policy. Student exchange activities are one of the programs of the policy. The purpose of this study was to determine the development of student civic skills in the student exchange program. The method used in this research is a case study, the data collection tools are observation, interviews, and field notes, and the research subjects are 23 Citizenship Education students. Data analysis was carried out by means of data reduction, data presentation, and drawing conclusions. The results showed that student exchange activities were able to develop intellectual abilities and student participation. Student exchange program, have a high awareness of communicating and being able to understand new knowledge.
\end{abstract}

Keywords: Civic Skills, Kampus Merdeka-Merdeka Belajar, Student Exchange.

\section{INTRODUCTION}

Until today, Indonesia is still faced with all the challenges. These challenges consist of various things, including unemployment, poverty, social inequality, and corruption [1]. This challenge is caused by various factors, one of which is the low quality of human resources. The low quality of human resources is an obstacle to the development process and efforts to reduce other social problems [2]. Looking at this, we can all know that human resources are a determining factor for the progress of a nation. Therefore, it is necessary to improve the quality of human resources so that the Indonesian nation is able to become a superior nation.

Human resources in Indonesia come from various groups, one of which is students. Students are elements of human resources that cannot be separated from the growth of a nation. The title "agent of change" is often assigned to students as educated people who receive higher education. Of course, as agents of change, students have an obligation to fight for the creation of various improvements to social problems that occur in society [3]. Therefore, in order to prepare students to become superior resources and be able to provide a change, students need to have civic skills as capital to create positive changes in people's lives.

Civic skills have an important role in creating human resources who are knowledgeable and able to participate in solving problems around them. However, the reality shows that the civic skills possessed by students are still relatively low. In this context, the low civic skills possessed by students are related to the low participation of students in implementing their knowledge for the benefit of society. This is driven by various circumstances, such as the increasingly widespread impact of globalization. The swift currents of globalization both directly and indirectly shape the attitude pattern of society, including students as part of it. Globalization has a negative impact on the Indonesian nation, one of which is the growth of an individualistic attitude or self-interest [4]. This causes the knowledge ability possessed by most students is still only for their interests rather than for the benefit of the community. Looking at the existing problems, we can conclude that it is important that a balance between knowledge abilities and participatory abilities is absolutely necessary. Therefore, civic skills are an important concept that must be implemented for the sake of changing the nation's life for the better.

Various efforts also need to be made to internalize civic skills in students. In 2020, the Government of Indonesia has issued the Independent LearningIndependent Campus (MK-BM) policy which is stated in the Minister of Education and Culture Regulation Number 3 of 2020 concerning National Standards for Higher Education. Through the MB-KM policy, students are equipped with soft skills and hard skills so that they 
are expected to have the readiness to meet the needs of the times and become graduates with excellent and personality [5]. One of the programs contained in the MB-KM policy is a student exchange program. Student exchange in MB-KM activities aims to foster attitudes in students which include an attitude of respect for various differences, an attitude of being able to collaborate, and a caring and sensitive attitude towards society and the environment [5]. hrough the MB-KM student exchange program, either directly or indirectly, students are fostered to have civic skills so that they have the readiness to bring change to the nation and state.

So, based on the presentation that has been delivered, the purpose of this study is to determine the development of student civic skills in the MB-KM student exchange program.

\section{THEORETICAL REVIEW}

\subsection{Civic Skill}

Civic skill is an important concept that is often studied in civic education. This is supported by Branson who argues that there are 3 important components in the study of Citizenship Education, including civic knowledgecivic knowledge (), civic skills (civics ability), and civic disposition (citizenship characteristics) [6]. Civic skill itself is defined as a skill that is the result of the development of civic knowledge with the aim that the knowledge gained by citizens can be directed to solve various problems of national and state life so that knowledge becomes meaningful [7]. Civic skills consist of intellectual skills and participation skills. For the life of citizens, civic skills have an important role. Civic Skill encourages a person to be able to give meaningful meaning to the ideal values contained in a nation, the ideals and goals of the state, as well as the rights of the majority and minorities [8]. Through civic skills, it is hoped that human resources will be able to use knowledge and intellectual abilities as much as possible for the life of the nation and state.

\subsection{Student Exchange Program}

exchange is a program that provides opportunities for students to gain learning from other schools as an activity to absorb various disciplines of science and technology, as well as an arena for cultural exchange [9]. Student exchanges are expected to be able to provide learning experiences for students outside the institution by upholding equality in learning [10]. Through student exchange, students from different study programs and universities are expected to be able to build collaboration skills as well as intellectual abilities and participation abilities. In addition to the goals for students, there are also exchange program goals for universities. For universities, student exchanges are part of joint degree programs and the opportunities provided by them are related to the transfer of innovations, increased competitiveness and market expansion [11].

\section{METHODS}

Research methods are a series of scientific methods used in order to obtain data for certain purposes [12]. This research uses a case study method with a qualitative approach. Case studies deal with "how" and "why" questions in which in this case the investigator has little control over events and the research focus leads to contemporary phenomena in real life [13]. The research subjects are Citizenship Education Students as many as 23 people who come from Yogyakarta State University and have carried out student exchange program activities at the Indonesian Education University. Data collection tools in the study were observations, interviews, and field notes during the process of implementing student exchange activities. Data analysis was carried out by means of data reduction, data presentation, and drawing conclusions.

\section{RESULTS AND DISCUSSION}

The MB-KM student exchange program must be implemented for each university independently according to the capacity of the university concerned [14]. So, the Indonesian Education University as one of the universities in Indonesia has organized student exchange program activities independently as a step to support the Merdeka Learning program - Merdeka Campus. Student exchange programs are carried out specifically by various study programs within the university. One of the study programs that have carried out this activity is the Citizenship Education Study Program.

The focus of the research is to focus on observing the development of civic skills through the MB-KM student exchange program in the Citizenship Education Study Program at the Indonesian Education University. Based on the results obtained, there are various student responses related to aspects of civic skills that are trying to be developed through the student exchange program. As previously mentioned, civic skills consist of two main abilities, namely intellectual abilities and participation abilities. Therefore, research studies are directed at these two abilities in the perceptual capacity of students.

The first study deals with the development of intellectual abilities for students. The further study is contained in the explanation as follows:
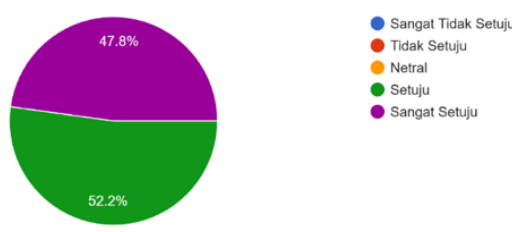

Figure 1. The percentage diagram of the learning level given by the study program is able to improve students' intellectual abilities. 
The picture above is a data representation of the results of interviews regarding the ability of the student exchange program to improve students' intellectual abilities in students. A total of $52.2 \%$ agreed that the student exchange program was able to improve students' intellectual abilities. Meanwhile, another $47.8 \%$ of students agreed that the student exchange program could improve students' intellectual abilities.

The data that has been submitted indicates that the student exchange program has been able to meet the indicators of civic skill development, namely an increase in students' intellectual abilities. The intellectual abilities that are developed for students are related to the learning that is in the learning series in accordance with the study program objectives, namely Citizenship Education. The intellectual abilities in question include various abilities to respond to the learning material provided. These abilities include the ability to identify material, the ability to describe, the ability to explain, the ability to analyze, the ability to evaluate opinions, the ability to give opinions, and the ability to defend opinions. Through these abilities, students are expected to have the knowledge and skills to be able to contribute to society in accordance with the capacity they carry.

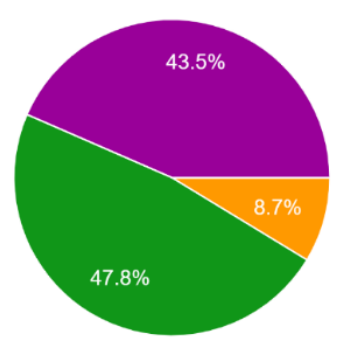

$$
\begin{aligned}
& \text { Sangat Tidak Setuju } \\
& \text { Tidak Setuju } \\
& \text { Netral } \\
& \text { Setuju } \\
& \text { Sangat Setuju }
\end{aligned}
$$

Figure 2. Percentage diagrams related to intellectual abilities that are directed to solving problems in the surrounding environment.

The picture above is a data representation of the results of interviews regarding student responses to the relevance of the intellectual abilities they get to solving surrounding problems. A total of $47.8 \%$ of students agreed and $43.5 \%$ of students strongly agreed that the intellectual abilities taught by the study program were directed at the ability to solve problems in the surrounding environment. Meanwhile, $8.7 \%$ of other students stated neutral.

Based on the statement above, it shows that the student exchange program is not only limited to developing intellectual abilities to support student capacity but is directed at the ability to solve problems in the surrounding environment. Learning is presented in an innovative way by emphasizing the intellectual development of students but is still associated with efforts to solve surrounding problems. This is also in accordance with the purpose of holding the MB-KM student exchange program in accordance with the Regulation of the Minister of Education and Culture (Permendikbud) Number 3 of 2020, one of which is having social sensitivity and concern for society and the environment. It is hoped that the development of intellectual abilities that are directed at solving surrounding problems can also develop student participation abilities through the learning provided in

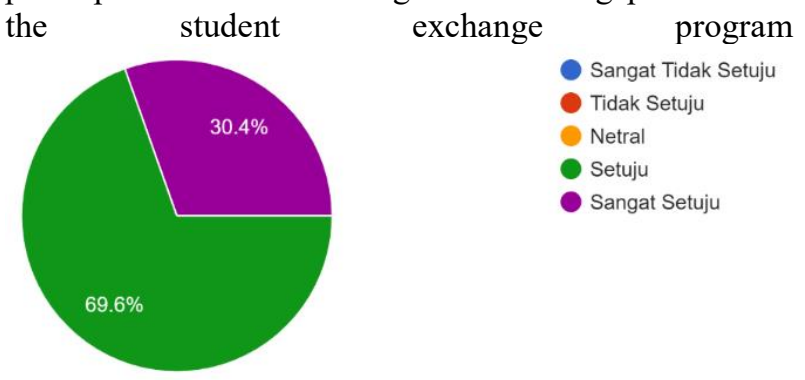

Figure 3. Diagram of the percentage of students' participation abilities in learning given the study program objectives.

The picture above is a data representation of the results of the interview regarding the ability of students to participate in the learning provided in the student exchange program. As many as $69.6 \%$ of students agreed that the learning provided by the study program was able to increase the ability of students to participate. Meanwhile, as many as $30.4 \%$ of students stated that they strongly agreed that the learning provided by the study program was able to increase students' participation abilities.

Based on the results of the research above, the data obtained indicate that all students think that participation skills have been developed in learning activities during the student exchange program. The development of participation skills provided in the student exchange program is embedded in the learning materials. Basically, the learned participation ability is a manifestation of the intellectual abilities that have been previously conveyed. The strengthening of intellectual abilities is then linked to the ability to participate so as to strengthen the process of internalizing civic skills for students.

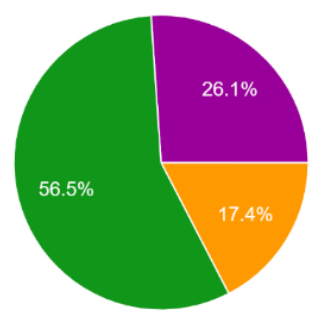

Sangat Tidak Setuju

Tidak Setuju

Netral

Setuju

Sangat Setuju

Figure 4. Diagram of the percentage of student participation abilities in solving public domain problems given in the student exchange program.

The participation capabilities provided are directed at solving problems in the public sphere. The picture above is a data representation of the results of the interview regarding the ability of student participation in solving public domain problems given in the student exchange 
program. A total of $56.5 \%$ of students agreed and $26.1 \%$ of students strongly agreed that the study program directs students in participation skills which refers to the ability to solve problems in the public sphere. Then, as many as $17.4 \%$ of students stated neutral.

Based on the results of the research above, the data obtained indicated that most of the students stated that they had obtained the development of participation skills directed at the realm of solving public problems. The development of participation skills is also directed at solving problems within the scope of community life. In fact, the ability to participate and problem-based learning influence each other. The application of problem-based learning strategies can increase students' active participation in the learning process [15]. It is hoped that active participation in the learning process can be implemented in the form of real participation for positive changes in the life of the nation and state.

In the course of civic skill development that has been implemented in the student exchange program, it certainly cannot be completely separated from the challenges and obstacles encountered. Based on the data obtained, there are still some obstacles in the student exchange process so that they also have an impact on the inhibition of the civic skill development process being carried out. Some of the obstacles found in the field include; (1) Socialization of the student exchange program has not been comprehensive so that students do not have sufficient information about the program; (2) In connection with the program that is still being held using the distance learning system due to the Covid-19 Pandemic, students also experience a number of obstacles related to the availability of inadequate internet access; and (3) the difficulty of students in adapting to the new environment and managing time.

Based on the findings above, we would like to examine several things regarding the findings of obstacles in the field. First, barriers related to socialization. Socialization is an effort to socialize something so that it becomes known [16]. Widespread and systematic socialization is important so that parties involved in program implementation can know, understand, and prepare for program implementation well [17]. Therefore, comprehensive socialization is needed so that students and all parties involved are able to carry out student exchange programs well and so that the development of civic skills carried out in the program can run more optimally.

Furthermore, regarding the constraints of inadequate internet access. It is undeniable that the ongoing Covid19 pandemic has made distance learning an alternative for some countries. Distance learning is defined as learning that is carried out without face to face, outside the classroom, and using an internet connection in learning activities [18]. This learning model can be carried out by students from different regional backgrounds simultaneously by utilizing an internet connection as the main means of supporting learning.
However, until now there are still some areas that have limited internet access so that this is also a challenge and obstacle in the student exchange program which is implemented using the distance learning model. Therefore, a solution from the government and universities is needed to overcome this problem so that the development of civic skills carried out in the student exchange program can run effectively even though it is carried out through distance learning.

Then, it was also found obstacles related to the adaptability and time management possessed by students. Student exchange involves students and lecturers from different regions and environments. Therefore, the ability to adapt is very important for the various elements involved. Adaptation is an adjustment to new environmental conditions (school, work, and so on) [16]. Adaptability certainly supports students to develop civic skills in student exchange programs. The process of absorbing learning materials to develop intellectual abilities and participation abilities will be easier when students are easy to respond quickly and well to things around them. Then, time management skills are one of the challenges in student exchange programs experienced by students. Time management is an ability related to planning, organizing, mobilizing and controlling (supervising) time productivity [19]. The ability to manage time is very important to support the implementation of civic skill development in the student exchange program. Good time management is an effort so that the development of civic skills can run effectively so that it can produce output in the form of increasing intellectual abilities and student participation abilities more optimally.

\section{CONCLUSION}

In general, the student exchange program in the series of Merdeka Belajar - Kampus Merdeka (MB-KM) policies is able to become a means of developing civic skills for students. The developed civic skills consist of intellectual abilities and participation abilities. Most students think that this program is able to improve their intellectual abilities and participation abilities. However, there are still some obstacles found in this program, including those related to less comprehensive socialization, internet access constraints, and adaptation and time management constraints. Therefore, in order to realize a more optimal student exchange program, intensive and systematic cooperation is needed from the government, universities, lecturers, and students so that efforts to develop civic skills for students can be realized properly.

\section{ACKNOWLEDGMENTS}

We would like to thank the Ministry of Education, Culture, Research and Technology, the Indonesian Education University, and Yogyakarta State University for their support. 


\section{REFERENCES}

[1] Humas Sekretariat Kabinet Republik Indonesia, "Program Kampus Merdeka Siapkan Mahasiswa yang Mampu Hadapi Tantangan Perubahan Global," setkab.go.id, 2021. https://setkab.go.id/program-kampus-merdekasiapkan-mahasiswa-yang-mampu-hadapitantangan-perubahan-global/ (accessed Oct. 02, 2021).

[2] Zakiah, "Dampak Peningkatan Kualitas Sumber Daya Manusia dan Pertumbuhan Ekonomi terhadap Penurunan Jumlah Penduduk Miskin di Provinsi Aceh," vol. 4, no. 1, pp. 30-53, 2013.

[3] I. S. Istichomaharani and S. S. Habibah, "Mewujudkan Peran Mahasiswa Sebagai 'Agent Of Change, Social Control, Dan Iron Stock," Pros. Semin. Nas. dan Call Pap. ke-2 "Pengintegrasian Nilai Karakter dalam Pembelajaran Kreat. di Era Masy. Ekon. ASEAN”2016, pp. 2-7, 2016.

[4] M. I. Musa, "Dampak Pengaruh Globalisasi Bagi Kehidupan Bangsa Indonesia," Pesona Dasar (Jurnal Pendidik. Dasar dan Humaniora), vol. 1, no. 4, 2015, doi: 10.24815/pear.v7i2.14753.

[5] M. Tohir, "Buku Panduan Merdeka Belajar Kampus Merdeka," 2020, doi: 10.31219/osf.io/ujmte.

[6] M. S. Branson, Belajar "Civic Education” dari Amerika (Terjemahan Syarifudin dkk). Yogyakarta: LKIS, 1999.

[7] T. Pangalila, "Peningkatan civic disposition siswa melalui pembelajaran Pendidikan Kewarganegaraan (PKn)," vol. 7, pp. 91-103, 2017, [Online]. Available: http://repository.unima.ac.id:8080/handle/1234567 $89 / 426$.

[8] Y. Hidayah and S. Sunarso, "Penguasaan civic skills aktivis badan eksekutif mahasiswa (studi di Universitas Negeri Yogyakarta)," Harmon. Sos. J. Pendidik. IPS, vol. 4, no. 2, pp. 153-164, 2018, doi: 10.21831/hsjpi.v4i2.9862.

[9] A. Kurniawan, "Pentingnya Pertukaran Pelajar untuk Tingkatkan Pengalaman 'International Exposure' Siswa,” Kompas.com, 2018. https://edukasi.kompas.com/read/2018/11/01/0851 4031/pentingnya-pertukaran-pelajar-untuktingkatkan-pengalaman-international (accessed Oct. 02, 2021).
[10] S. Latifah et al., "Pertukaran Pelajar Unram-UPM : Inovasi Pembelajaran Mbkm Dalam Menumbuhkan Ketangguhan Lulusan Sarjana Kehutanan," J. PEPADU, vol. 2, no. 1, pp. 46-51, 2021, doi: 10.29303/jurnalpepadu.v2i1.290.

[11] I. Shopova, R. Development, E. Arabska, and R. Development, "Organizing Successful Foreign Students Exchange,” no. January 2013, 2016.

[12] Hamid Darmadi, Metode Penelitian Pendidikan dan Sosial. Bandung: Alfabeta, 2013.

[13] R. K. Yin, Application of Case Study Research (2nd ed. Vol. 34). Thousand Oaks: Sage Publication, 2003.

[14] S. F. \& D. I. Nisrina Nurul Insani, "Persepsi Mahasiswa Tentang Kurikulum Merdeka Belajar Kampus Merdeka," vol. 3, no. 2, p. 6, 2021.

[15] I. Murray and M. Savin-Baden, "Staff Development in Problem-based Learning," Teach. High. Educ., vol. 5, no. 1, pp. 107-126, 2000, doi: $10.1080 / 135625100114993$

[16] dan T. R. I. Badan Pengembangan dan Pembinaan Bahasa, Kementerian Pendidikan, Kebudayaan, Riset, "Kamus Besar Bahasa Indonesia," Badan Pengembangan dan Pembinaan Bahasa, Kementerian Pendidikan, Kebudayaan, Riset, dan Teknologi Republik Indonesia, 2016. https://kbbi.kemdikbud.go.id/.

[17] S. Fitriasari, D. Budimansyah, N. N. Insani, and S. R. Aulia, "Implementasi Program Belajar Di Luar Kampus, Merdeka Belajar - Kampus Merdeka Program Studi Pendidikan Kewarganegaraan,' Gener. Pancasila, vol. 1, no. 1, 2021, [Online] Available:http://www.openjournal.unpam.ac.id/ind ex.php/gnp/article/view/11252.

[18] J. W. Kusuma and H. Hamidah, "Perbandingan Hasil Belajar Matematika Dengan Penggunaan Platform Whatsapp Group Dan Webinar Zoom Dalam Pembelajaran Jarak Jauh Pada Masa Pandemik Covid 19," JIPMat, vol. 5, no. 1, 2020, doi: 10.26877/jipmat.v5i1.5942.

[19] M. SYELVIANI, "Pentingnya Manajemen Waktu Dalam Mencapai Efektivitas Bagi Mahasiswa (Studi Kasus Mahasiswa Program Studi Manajemen Unisi)," J. Anal. Manaj., vol. 6 (1), pp. 66-75, 2020. 